\title{
THE INVOLVEMENT OF SLOVAKIA IN INTERMEDIATE TRADE
}

\author{
Júlia Ďurčová ${ }^{1}$ \\ Dominika Oravcová ${ }^{2}$
}

Received: October 9, 2018 / Revised: January 15, 2019/ Accepted: March 15, 2019

(C) Association of Economists and Managers of the Balkans, 2019

\begin{abstract}
Fragmentation of production processes across borders represents a new paradigm of foreign trade. The new organization of production processes at the global or regional level opposite to a national level has been manifested by huge increase of trade in intermediate inputs. The world trade is growing fast and is largely driven by the intermediate trade. Countries that do not significantly engage in intermediate trade and achieve low labour productivity growth rates, have seen lower growth rates of value added. Therefore, the aim of this article is to investigate the involvement of Slovakia in use and trade in intermediates. We analyze the import and export of intermediates using data from world input-output database. The results for Slovakia show that the trade in intermediates has experienced a significant shift over last 14 years. The volume of intermediate trade remarkably grown moreover the dynamic of its change overcomes the growth of gross output as well as value added. At the same time, the Slovak industrial sectors have increased demand for imported intermediate inputs; furthermore the difference between imported and exported intermediate inputs rises.
\end{abstract}

Keywords: Trade in intermediates, Global value chains, Input-output tables, WIOD

JEL Classification F14 $\cdot$ F62 $\cdot$ L60

This paper was presented at the Second International Scientific Conference on IT, Tourism, Economics, Management and Agriculture - ITEMA 2018 - November 8, 2018, Graz, Austria, www.itema-conference.com

Júlia Ďurčová

julia.durcova@tuke.sk

1 Faculty of Economics, Technical University of Košice, Nemcovej 32, 04001 Košice, Slovak Republic

2 Faculty of Economics, Technical University of Košice, Nemcovej 32, 04001 Košice, Slovak Republic 


\section{INTRODUCTION}

The development of global production chains represents key component of the current economic globalization. At present, almost every final product consists of parts that have been produced in several countries. The international division of production and its development has contributed to the increase of intermediate products use at every stage of the production process. This increase in intermediate trade (for example with semi-finished products, different parts or components, etc.) reflects the enormous increase in foreign direct investment flows (EÚ, 2008). Fragmentation of production processes across borders has led to the relocation of tasks that could be carried out on the domestic market. In terms of employment, exports are characterized by positive effects, while offshoring is associated with a decline in domestic employment at company level. However, the effects of offshoring on employment at the domestic company level depend on various factors - type of countries, policies, conditions, etc. (Egger et al. 2015). For these reasons the aim of this paper is to investigate the involvement of Slovakia in offshoring activities via the analysis of trade and use of domestic and imported intermediates.

The paper is divided into four sections. Following the introduction, the relevant empirical literature is reviewed in Section 2. In Section 3 we provide an overview of methodology and empirical results. Finally, concluding remarks are made in Section 4.

\section{LITERATURE REVIEW}

World trade in goods and services is growing rapidly due to the reduction of transport and communication costs. This growth is largely driven by intermediate products trade (Hummels et al. 2001). A significant part of the foreign trade in intermediate products is realized within the networks of TNC while independent suppliers (small and medium-sized enterprises) are also gradually involved as subcontractors. Participation in the global production chain (GVC) and its profit require an open and transparent business and investment regime as well as investment in education, production capacity development and infrastructure (MZV, 2013). Significant increases in value added have been recorded in particular by countries which have increased their involvement in trade with intermediates. Profits from intermediate trade more than offset losses in market shares in the final products trade. Countries that do not significantly engage in intermediate trade and achieve low labour productivity growth rates, have seen lower growth rates of value added. This development has negatively affected the country's economic growth in the next period (Lábaj, 2017; Lábaj 2014). The euro area, the main source of foreign value added in exports for most member countries and its share is more stable than that of other trade blocks. The growing relevance of external suppliers does not reflect a weakening of the production links within the euro area, being instead a substitution of domestic value added by extra euro area sourcing (Amador et al. 2015).

Changes due to GVC were reflected in the strong growth of trade with intermediates. However, in the next future, there may be changes in business costs due to the introduction of different regional barriers and increased protection. In addition, technological innovation, robotization can stimulate the restoration of production localization in developed countries, which can significantly affect the import intensity of world GDP (Los, Timmer, De Vries, 2015). 


\section{METHODOLOGY AND RESULTS}

Analyzing the current trends in international fragmentation of production requires consistent timelines of the world's Input-Output Tables (WIOT). WIOD is the first public database that contains new trend information and provides the ability to analyze the consequences of fragmentation (Timmer et al., 2015). Input-Output Tables on which the analysis will be based are derived from a set of harmonized national supply and use tables that are linked to detailed bilateral trade-related international data from a variety of statistical sources such as the OECD, UN National Accounts and trade Statistics of IMF (Escaith, Timmer, 2012). The latest updated 2016 database contains data from 2000 to 2014 and includes 43 countries and the rest of the world classified according to the ISIC Rev.4 in 56 sectors. Using WIOT allows us to capture both direct and indirect links between industries and countries. They provide more detailed information on inter-sectoral flows and flows of goods and services at the end-use (Rojíček, Vavrla, 2006).

The world intermediate trade develops dynamically, since 2000 its value almost tripled. Due to the 2008 crisis slowdown the growth rates resumed only in 2010 (Fig.1). In the case of Slovakia, the development is even more dramatic. The total volume of intermediate consumption grew 4.6 times over the period 2000-2014. Annual growth rates, especially at the beginning of the monitored period gained $35 \%$. However, global economic slowdown has contributed to significantly lower growth rates since 2008. Up to 2008 the FDI was dynamically growing particularly in industrial production dominated by the automotive sector. In this period, the character of the Slovak economy reinforced to export-oriented with the dominance of automotive industry.
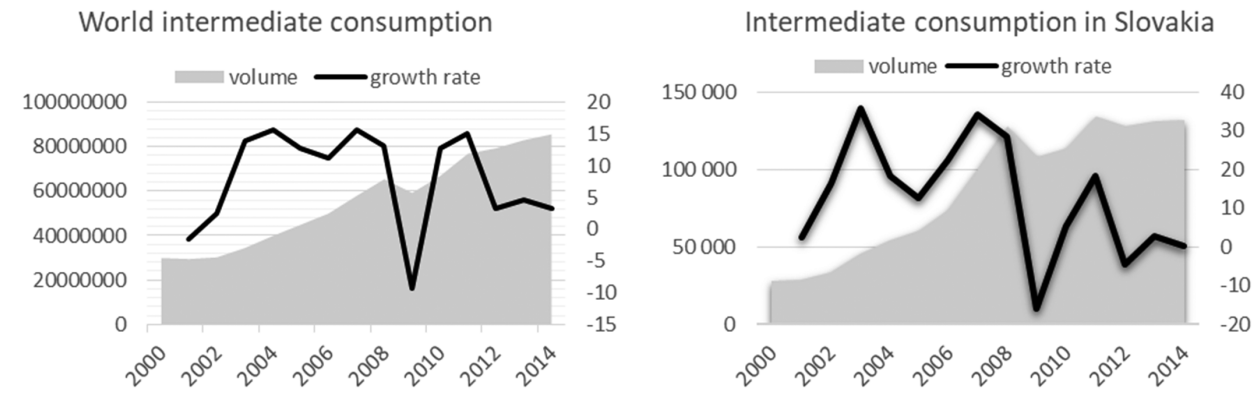

Figure 1: The development of world and Slovak intermediate consumption Source: own graph, Data from WIOD

The volume of intermediate trade remarkably grown moreover the dynamic of its change overcome the growth of gross output as well as value added (Fig. 2). Gross output and value added volumes have grown approximately 2.4 times over this period, compared to 4.6 increase in intermediate production. Among the sectors, the highest gross output growth was recorded for the manufacture of motor vehicles (automotive industry 524\%), manufacture of computers, electronic and optical products (753\%) or manufacture of machinery and equipment (224\%), but also computer programming, consultancy and related activities (532\%). Growth in value added was also significant, but slower in these sectors compared to growth in gross production (manufacture of motor vehicles $398 \%$, manufacture of computers $270 \%$, manufacture of machinery and equipment $158 \%$, computer programming 590\%). The growth of intermediate consumption between 2000 and 2014 increased by $1000 \%$ in the manufacture of computer, by $547 \%$ in the manufacture of motor vehicles and by $474 \%$ in the computer programming sector. 


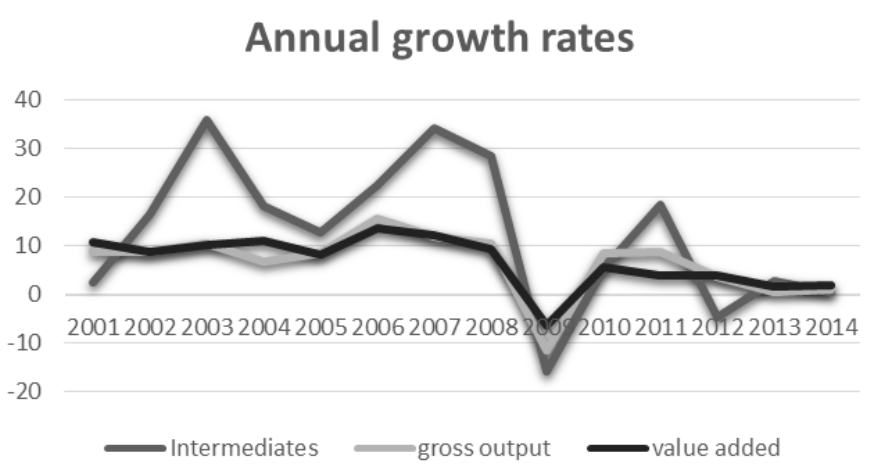

Figure 2: The average intermediate inputs, gross product and value added annual rates of growt Source: own graph, Data from WIOD

The growing participation in the GVCs moves the structure of intermediate consumption in Slovakia as well. While in 2000 almost $76 \%$ inputs had domestic origins, in 2014 it was $10 \%$ less. Consequently the volume of imported intermediate consumption significantly increased (the share of imported intermediate in total intermediate consumption raised from $24 \%$ in 2000 to $40 \%$ in 2014) (Fig. 3).

Durable goods (for investment or consumer use) are mostly produced in large international production networks, while services have usually domestic origin. Hence the import of intermediates is more apparent in manufacturing services (Fig. 4). If the national economy is more oriented on durable goods production rather than services it may increase sensitivity to external shocks with more pronounced manifestations.

Up to 2008 the rates of annual import and export growth reached more than $20 \%$ (Fig. 5). In 2009 the slowdown of world economy influenced the development in Slovakia as well. Moreover, the difference between imported and exported intermediates grew. Furthermore the share of manufacturing sectors in export of intermediates decreased ( $81 \%$ in 2000 and $72 \%$ in 2014) and contrary the share of services grew (19\% in 2000 and $28 \%$ in 2014).

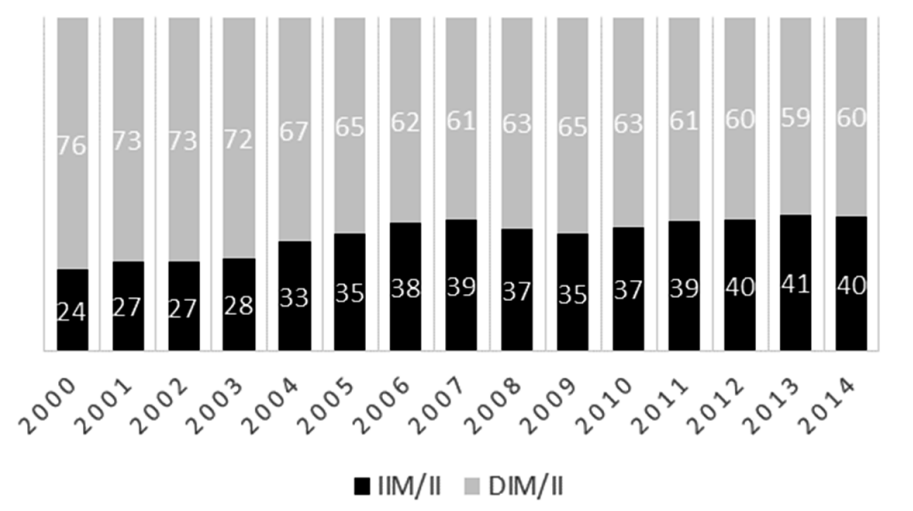

Figure 3: The share of domestic (DIM) and imported (IIM) intermediates in total Slovak intermediate consumption (II).

Source: own graph, Data from WIOD 


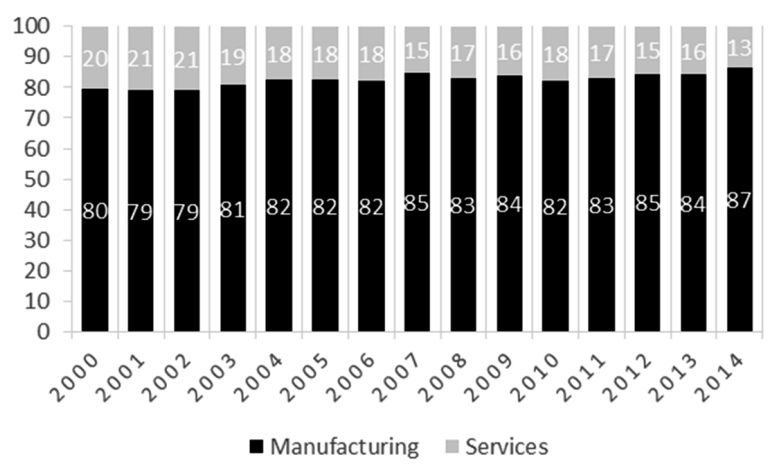

Figure 4: The share of imported intermediates in the Manufacturing and Services Source: own graph, Data from WIOD

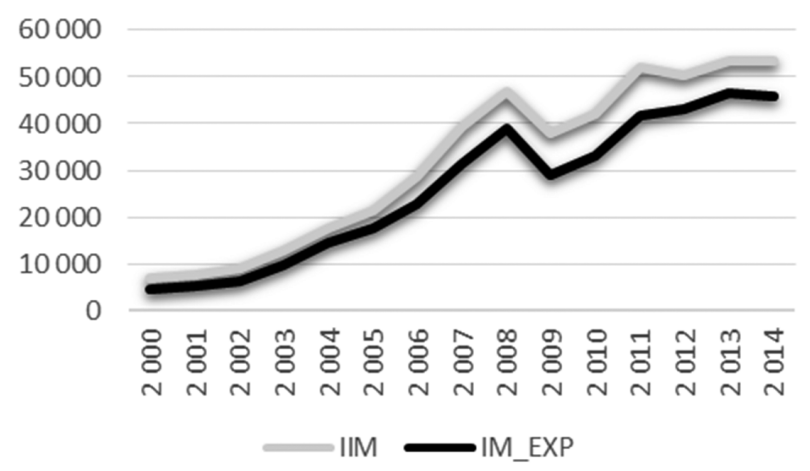

Figure 5: The volume of imported (IIM) and exported (IM_EXP) intermediates Source: own graph, Data from WIOD

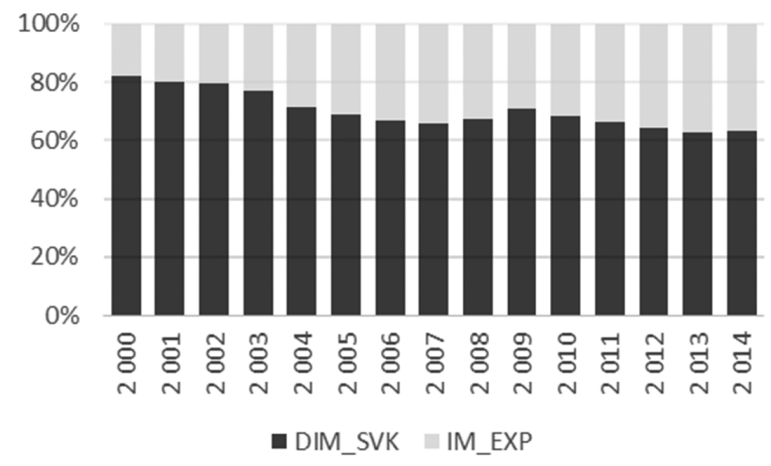

Figure 6: The share of domestic intermediate consumed in Slovakia (DIM) and exported from Slovakia (IM_EXP). Source: own graph, Data from WIOD

The changes are clearly visible in consumption of intermediates as well. While in 2000 more than $80 \%$ of domestic intermediates were used in Slovak production and 17\% were exported, in 2014 the share of export represented already $37 \%$ (Fig. 6). It also manifests the growing involvement of Slovakia in GVCs as well as the risk of growing external fluctuations influence. 
The manufacturing sectors exported the intermediates more intensively (Tab.1). Although the involvement of individual manufacturing sectors in export of intermediates during 14 years have changed. Up to 2000, Manufacture of basic metal held the dominant exporting position (25\%), while in 2014 it was automotive industry (18\%). The export of intermediates in 2000 was concentrated to less number of countries. The main destination of Slovak intermediate export was Germany and neighbor countries (54\%). In 2014 the share of countries is more disperse, the export widen to other countries like Russia, Great Britain, France as well as Rest of world. However, almost $72 \%$ of Slovak intermediate is exported to the EU markets (38\% to Euro zone countries).

In the period 2000-2014 the import of intermediates to Slovakia grew by $7.8 \%$. More than half of imported intermediate (59\%) was demanded only by the six industrial sectors; moreover just automotive industry required $26 \%$. The automotive industry in Slovakia is highly depended on import of intermediates that clearly reveal the lower position of Slovakia on its global value chain. Moreover, the sector Manufacture of computer with lower share on the total Slovak output creation (3.4\% while automotive industry $12.23 \%$ ) engaged on import of intermediates by more than $11 \%$. However the share of this sector on Slovak value added creation is no more than $0.96 \%$ (the automotive industry 3.84\%) witch raises the question whether this sector is beneficial for Slovak economy.

Table 1: Intermediate export from Slovakia by industrial sectors and country of destination Source: Data from WIOD

\begin{tabular}{|l|r|l|r|}
\hline Export by industrial sectors & $\mathbf{2 0 0 0}$ & & 2014 \\
\hline Manufacture of basic metals & $25 \%$ & $\begin{array}{l}\text { Manufacture of motor vehicles, trailers } \\
\text { and semi-trailers }\end{array}$ & $18 \%$ \\
\hline $\begin{array}{l}\text { Manufacture of motor vehicles, trailers } \\
\text { and semi-trailers }\end{array}$ & $9 \%$ & Manufacture of basic metals & $10 \%$ \\
\hline $\begin{array}{l}\text { Land transport and transport via } \\
\text { pipelines }\end{array}$ & $5 \%$ & $\begin{array}{l}\text { Manufacture of rubber and plastic } \\
\text { products }\end{array}$ & $6 \%$ \\
\hline $\begin{array}{l}\text { Manufacture of paper and paper } \\
\text { products }\end{array}$ & $5 \%$ & Real estate activities 6\% & $6 \%$ \\
\hline $\begin{array}{l}\text { Wholesale trade, except of motor } \\
\text { vehicles and motorcycles }\end{array}$ & $5 \%$ & $\begin{array}{l}\text { Manufacture of machinery and } \\
\text { equipment n.e.c. }\end{array}$ & $6 \%$ \\
\hline $\begin{array}{l}\text { Manufacture of machinery and } \\
\text { equipment n.e.c. }\end{array}$ & $5 \%$ & Manufacture of electrical equipment & $5 \%$ \\
\hline Others & $46 \%$ & Others & $48 \%$ \\
\hline Export by country of destination & $\mathbf{2 0 0 0}$ & & $\mathbf{2 ~ 0 1 4}$ \\
\hline Germany & $23 \%$ & Rest of world & $12 \%$ \\
\hline Czech republic & $15 \%$ & Germany & $11 \%$ \\
\hline Rest of world & $11 \%$ & Czech republic & $10 \%$ \\
\hline Austria & $8 \%$ & Hungary & $7 \%$ \\
\hline Poland & $8 \%$ & Austria & $7 \%$ \\
\hline Italia & $6 \%$ & Poland & $6 \%$ \\
\hline Others & $30 \%$ & Others & $48 \%$ \\
\hline
\end{tabular}

Furthermore the significant change appears in territorial structure of intermediate import (Tab. 2). While the German market rest the dominant source of Slovak intermediate import, the demand from the countries as Austria or Russia decreased (the share of intermediate import from these countries on total intermediate import). Generally, the main partners are EU countries although the 
intertemporal comparison showed that the share from these counties decreased $(68 \%$ of imported intermediate from EU in 2000 while 66\% in 2014). The Slovak manufacturing sectors increased the import of intermediates from the Rest of World as South Korea. Moreover, the share of import from the countries of Euro zone decreased (from $47 \%$ in 2000 to $37 \%$ in 2014). That's the reason why it can't be generally stated that the growing relevance of external suppliers does not reflect a weakening of the production links within the euro area, as argue Amador et al. (2015).

Table 2: Intermediate inputs import by industrial sectors and countries Source: Data from WIOD

\begin{tabular}{|l|r|l|r|}
\hline Import by industrial sectors & $\mathbf{2 0 0 0}$ & & 2014 \\
\hline $\begin{array}{l}\text { Manufacture of motor vehicles, trailers } \\
\text { and semi-trailers }\end{array}$ & $13 \%$ & $\begin{array}{l}\text { Manufacture of motor vehicles, trailers } \\
\text { and semi-trailers }\end{array}$ & $26 \%$ \\
\hline $\begin{array}{l}\text { Manufacture of coke and refined } \\
\text { petroleum products }\end{array}$ & $10 \%$ & $\begin{array}{l}\text { Manufacture of computer, electronic } \\
\text { and optical products }\end{array}$ & $11 \%$ \\
\hline Manufacture of basic metals & $9 \%$ & $\begin{array}{l}\text { Manufacture of coke and refined } \\
\text { petroleum products }\end{array}$ & $7 \%$ \\
\hline $\begin{array}{l}\text { Electricity, gas, steam and air } \\
\text { conditioning supply }\end{array}$ & $7 \%$ & $\begin{array}{l}\text { Electricity, gas, steam and air } \\
\text { conditioning supply }\end{array}$ & $6 \%$ \\
\hline Construction & $6 \%$ & Manufacture of basic metals & $5 \%$ \\
\hline Manufacture of electrical equipment & $5 \%$ & $\begin{array}{l}\text { Manufacture of rubber and plastic } \\
\text { products }\end{array}$ & $4 \%$ \\
\hline Others & $50 \%$ & Others & $41 \%$ \\
\hline Import by countries & $\mathbf{2 0 0 0}$ & & $\mathbf{2 0 1 4}$ \\
\hline Germany & $26 \%$ & Germany & $20 \%$ \\
\hline Russia & $19 \%$ & Rest of world & $17 \%$ \\
\hline Czech republic & $12 \%$ & Czech republic & $14 \%$ \\
\hline Austria & $8 \%$ & Poland & $7 \%$ \\
\hline Rest of world & $6 \%$ & South Korea & $6 \%$ \\
\hline Poland & $4 \%$ & Hungary & $51 \%$ \\
\hline Others & $25 \%$ & Others & \\
\hline
\end{tabular}

\section{CONCLUSION}

Slovakia has experienced a significant change in trade in intermediates over the last 14 years. The volume of intermediate trade remarkably grown moreover the dynamic of its change overcome the growth of gross output as well as value added. Up to 2008, many investments were coming to Slovakia, mainly to industrial sectors e.g. automotive industry. The manufacturing sectors have stronger intermediate inputs demand as well as capital use and lower demand for labour. The growing involvement of Slovak manufacturing sectors in the global production chains influenced the intermediate consumption too. While in 2000 almost $76 \%$ inputs has domestic origins, after 14 years it's $10 \%$ less. Consequently the volume of imported intermediate consumption significantly increased. Moreover, the difference between imported and exported intermediates grew. Furthermore the share of manufacturing sectors on exports of intermediates decreased. The changes are clearly visible in consumption of intermediates too. While in 2000 more than $80 \%$ of domestic intermediates were used in Slovak production and 17\% were exported, in 2014 the share of export represented already $34 \%$. The export of intermediates in 2000 was concentrated 
to less number of countries. The main destination of Slovak intermediate export was Germany and neighbor countries. In 2014 almost $72 \%$ of Slovak intermediate is exported to the EU markets (38\% to Euro zone countries). Concerning import of intermediates, the main partners are still EU countries however the share of import from these countries decreased. The Slovak manufacturing sectors increased the import of intermediates from the countries as South Korea. More than half of imported intermediate is demanded only by six industrial sectors; moreover $26 \%$ is destined to automotive industry.

\section{ACKNOWLEDGEMENT}

This paper was written in connection with scientific project VEGA no. 1/0961/16. Financial support from this Ministry of Education`s scheme is also gratefully acknowledged.

\section{REFERENCES}

Amador, J. Cappariello, R. \& Stehrer, R. (2015). Global Value Chains: A View From The Euro Area. Asian Economic Journal, 29(21), 99-120. https://doi.org/10.1111/asej.12050

Egger, H., Kreickemeier, U. \& Wrona, J. (2015). Offshoring Domestic Jobs. Journal of International Economics, 97 (1), 112-125. https://doi.org/10.1016/j.jinteco.2015.03.010

Escaith, H. \& Timmer, M. (2012). Global value chains, trade, jobs, and environment: The new WIOD database. VOX, CEPR's Policy Portal. https://voxeu.org/article/new-world-input-output-database

EÚ (2008). Úradný vestník Európskej únie: Stanovisko Európskeho hospodárskeho a sociálneho výboru na tému „Integrácia svetového obchodu a outsourcing. Čelit’ novým výzvam“, from http://eurex.europa.eu/legalcontent/SK/TXT/PDF/?uri=CELEX:52007IE1255\&from=SK

Hummels, D., Ishii, J. \& Yi, K.M. (2001). The nature and growth of vertical specialization in world trade. Journal of International Economics, 54(1), 75-96. https://doi.org/10.1016/ S0022-1996(00)00093-3

Lábaj, M. (2017). Structural Decomposition of Global Value Chains: Slovak Economy in an International Context, Politicka Ekonomie, 65(5), 562-582

Lábaj, M. (2014). Štrukturálne aspekty ekonomického rozvoja - Slovenská ekonomika v globálnych súvislostiach. Ekonóm, Bratislava, 2014. ISBN 978-80-7144-223-3.

Los B. , Timmer P. M. \& De Vries G. J. (2015). How global are global value chains? A new approach to measure international fragmentation. Journal of regional science, 55(1), 66-92

MZV - Ministry of foreign and European affairs of the Slovak Republic (2013). Globálne hodnotové ret'azce a obchod meraný pridanou hodnotou.from

https://www.mzv.sk/documents/1505263/1512379/Glob\%C3\%A1lne+hodnotov\%C3\%A9+re\%C5\%A5azce.pdf/1ec9be6a-082c-4df8-bf83-b4c9b4dbc77b

Rojíček, M. \& Vavrla, L. (2006). Sestavování symetrických input-output tabulek a jejich aplikace. Statistika, 43 (1), 28-43. ISSN 0322-788X

Timmer M.P., Dietzenbacher E., Los B., Stehrer R., \& De Vries G.J. (2015) An Illustrated User Guide to the World Input-Output Database: the Case of Global Automotive Production. Review of International Economics, 23 (3), 575-605, DOI: 10.1111/roie.12178

World Input Output Database, National Input Output Tables-Slovakia. 2000 - 2016. 2016 Release. (2017), from: http://www.Wiod.Org/Database/Niots16. 